\title{
KNOWLEDGE OF DIABETIC PATIENTS ABOUT THEIR DISEASE BEFORE AND AFTER IMPLEMENTING A DIABETES EDUCATION PROGRAM ${ }^{1}$
}

Liudmila Miyar Otero

Maria Lúcia Zanetti ${ }^{3}$

Michelle Daguano Ogrizio ${ }^{4}$

Miyar Otero L, Zanetti ML, Daguano Ogrizio M. Knowledge of diabetic patients about their disease before and after implementing a diabetes education program. Rev Latino-am Enfermagem 2008 março-abril; 16(2):231-7.

The purpose of this quasi-experimental, prospective and comparative study is to evaluate the knowledge that diabetic patients have about their disease before and after implementing a Diabetes Education Program. Fifty-four diabetic patients participated in the study, which occurred from April 2004 to April 2005. Data collection was performed using a questionnaire. The study population was characterized as adult and elderly subjects, with ages between 29 and 78 years; 60 years, on the average; Most participants were female 40/54 (74.1\%); white $32 / 54$ (59.3\%); married 37/54 (68.5\%); retired 23/54 (42.6\%); with incomplete primary education 32/54 (59.3\%); and an income of one to two minimum wages 16/54 (29.6\%). The patients' knowledge regarding their disease increased significantly $(p<0.05)$; especially considering the general topics concerning diabetes mellitus: concept of the disease, physiopathology and treatments; other topics that stood out were physical activity and nutrition.

DESCRIPTORS: nursing; diabetes mellitus; health education

\section{EL CONOCIMIENTO DEL PACIENTE DIABÉTICO SOBRE SU ENFERMEDAD, ANTES Y DESPUÉS DE LA IMPLEMENTACIÓN DE UN PROGRAMA DE EDUCACIÓN EN DIABETES}

Este es un estudio cuasiexperimental, prospectivo, comparativo; tuvo por objetivo, evaluar el conocimiento de los pacientes diabéticos acerca de su enfermedad antes y después de la implementación de un Programa 1 de Educación en Diabetes. Participaron 54 pacientes diabéticos, de abril de 2004 a abril de 2005. Para la recolección de los datos, se utilizó un cuestionario. La población se caracterizó por ser pacientes adultos y ancianos, con edad entre 29 y 78 años, con mediana de 60 años; predominio del sexo femenino 40/54 (74,1\%); blancos 32/54 (59,3\%); casados 37/54 (68,5\%); jubilados 23/54 (42,6\%); enseñanza fundamental incompleta 32/54 (59,3\%); y renta entre 1 y 2 salarios mínimos 16/54 (29,6\%). Con relación al conocimiento de los pacientes acerca de su enfermedad, se constató un aumento significativo $(p<0,05)$, destacándose los tópicos generales de diabetes mellitus: concepto, fisiopatología y tratamiento; otros tópicos importantes fueron la actividad física y la alimentación.

DESCRIPTORES: enfermería; diabetes mellitus; educación en salud

\section{CONHECIMENTO DO PACIENTE DIABÉTICO ACERCA DE SUA DOENÇA, ANTES E DEPOIS DA IMPLEMENTAÇÃO DE UM PROGRAMA DE EDUCAÇÃO EM DIABETES}

É um estudo quase-experimental, prospectivo, comparativo. O objetivo foi avaliar o conhecimento dos pacientes diabéticos acerca da doença, antes e depois da implementação de um Programa de Educação em diabetes. Participaram 54 pacientes diabéticos, de abril de 2004 a abril de 2005. Na coleta de dados, utilizou-se um questionário. A população caracterizou-se por pacientes adultos e idosos, com idade entre 29 e 78 anos, com mediana de 60 anos, com predomínio do sexo feminino (40/54-74,1\%), brancos (32/54-59,3\%), casados (37/54-68,5\%), aposentados (23/54-42,6\%), ensino fundamental incompleto (32/54-59,3\%) e renda entre um e dois salários mínimos (16/54-29,6\%). Quanto ao conhecimento dos pacientes acerca de sua doença, houve aumento significativo $(p<0,05)$, com destaque para os tópicos gerais do diabetes mellitus: conceito, fisiopatologia e tratamento; outros tópicos destacados foram a atividade física e alimentação.

DESCRITORES: enfermagem; diabetes mellitus; educação em saúde

${ }^{1}$ Article extracted from Doctoral Dissertation; ${ }^{2}$ RN, Nursing Doctoral Student; ${ }^{3}$ Associate Professor; ${ }^{4}$ Nursing Undergraduate Student, University of Sao Paulo at Ribeirao Preto, College of Nursing, WHO Collaborating Centre for Nursing Research Development, Brazil. 


\section{INTRODUCTION}

The need to provide diabetic patients with continuous follow-up and support by a multiprofessional health team has been demonstrated by two large studies performed in the 1990s. These studies showed that a systematic follow-up avoided or delayed chronic complications in these patients during the course of the diabetes mellitus.

After these studies were published, the importance of the multi-professional health team in the education of diabetic patients has been acknowledged. Furthermore, numerous educational projects have been developed at international and national levels ${ }^{(3-6)}$

Education, as an essential aspect in diabetic patients' treatment, has been recommended by Bouchardat since 1975. Its importance has been demonstrated in many studies, performed in communities with different socioeconomic and cultural levels ${ }^{(3-6)}$. In this sense, effective diabetes education requires training, knowledge, educational skills, communication and listening abilities, understanding and negotiation skills from the multi-professional health team ${ }^{(6)}$.

The need to develop teaching or health education practice activities for diabetic patients and their families is associated with the prevention of complications through self-management of the disease, which permits patients to live with it better ${ }^{(7-8)}$.

Education toward diabetes mellitus selfmanagement is the process of teaching patients to administrate their disease. The goals in diabetes education consist in improving metabolic control, preventing acute and chronic complications and improving one's quality of life at reasonable costs.

However, there is a significant knowledge and skill deficit in $50 \%$ to $80 \%$ of diabetic individuals ${ }^{(9)}$. Less than half the patients with type 2 diabetes are actually able to monitor their blood glucose, which is verified through hemoglobin $A 1 c^{(10)}$. Studies report that, in order to make an effective evaluation of the results reached through a diabetes education program, pre and post-intervention assessments are called for. It is worth emphasizing that almost a fourth of researchers find it difficult to evaluate the effectiveness of interventions ${ }^{(5,8,10)}$.

Since diabetes education is recognized as an essential part of diabetic patients' treatment, a Diabetes Education Program was implemented in a research and university extension center, in a city in the interior of São Paulo state, based on the Standards for the development of Education Programs for People with Diabetes in the Americas ${ }^{(6)}$.

\section{OBJECTIVE}

To evaluate the knowledge of diabetic patients about their disease before and after the implementation of a Diabetes Education Program.

\section{METHODOLOGY}

This quasi-experimental, prospective, comparative (before and after) study was performed from August 2003 to April 2005, at the Nursing Education Center for Adults and the Elderly (CEEAI) of the University of São Paulo at Ribeirão Preto College of Nursing. To perform this study, the researchers counted on a multi-professional team formed by nurses, endocrinologists, nutritionists, psychologists, physical educator and nursing and psychology undergraduates.

Fifty-four diabetic patients participated in the study (two patients with type 1 and 52 with type 2). The diabetes mellitus diagnosis was obtained through fasting plasmatic glucose testing. Patients were men and women from Ribeirão Preto and the region (São Paulo state), registered at the diabetic patient care service that uses the Staged Diabetes Management (SDM) Protocol ${ }^{(5)}$ at the CEEAI, from April 2004 to April 2005.

To design the data collection instrument, the authors chose sociodemographic variables (age, gender, skin color, marital status, education, family income and occupation) and those associated with the patients' knowledge about their disease.

The project was approved by the Ribeirao Preto College of Nursing Research Ethics Committee, in agreement with resolution 196/96, which regulates "research involving human beings".

Procedures

A ten-part questionnaire with 41 questions was administered. The first part contained data regarding sociodemographic variables, and the second general questions about diabetes. The third part addressed 
physical activity, the fourth data regarding food and eating, the fifth foot care and the sixth covered patients' knowledge about clinical parameters. The seventh part was about hypoglycemia information, the eight about chronic complications, the ninth addressed special situations and, finally, the tenth part addressed family support. Three diabetes specialists reviewed this questionnaire, and suggested changes regarding the questions' sequence and content. After making the suggested changes, a pilot test was carried out with six patients for a final adjustment of the instrument.

This questionnaire was administered at two specific moments; first in April 2004 and, second, in April 2005, after implementing a Diabetes Education Program.

The researchers carried out face-to-face interviews, with an average duration of 20 minutes. The answers were registered directly in the questionnaire, during the interviews.

The Education Program was developed based on the standardization for the development of education programs for people with diabetes in the Americas $^{(6)}$. The programs lasted 12 months and took place every Tuesday from 2 to 5 PM. The program was put in practice in line with these specific teaching strategies: group sessions in a classroom, using educational lectures, and having individual sessions with a view to reinforcing the instructions given in each nursing consultation. The addressed themes were: diabetes concept, physiopathology and treatment, physical activity, food and eating, foot care and examination, self-monitoring, hypoglycemia, chronic complications, special situations and family support.

The lectures involved stages for warm-up, development, and finalization. The contents were developed using teaching strategies like simulations, dramatizations, walks in the park, experience reports, celebrations (Christmas, Easter, June festivals, birthdays and others), theoretical classes, demonstrations and others. The educational material used included posters, figures, slides, overhead projector, slide projector, fliers, and demonstration material, like syringes, needles, glucose monitor, lances, cotton, alcohol, scale and others. The selected content was organized in topics for better visualization.

Data organization and analysis

To organize and analyze the data, a database was developed through double typing, using SPSS
11.5 software. The data were presented as absolute figures, percentages and absolute frequency distributions. The patients' responses concerning their knowledge about the disease were analyzed, considering the nine topics in the questionnaire. Each correct answer received score 1 and, thus, the total score for each topic in the questionnaire was obtained before and after implementing the Diabetes Education Program. The t-significance test was used for paired samples $(p<0.05)$.

\section{RESULTS}

Characterization of the study population according to sociodemographic variables

The study investigated fifty-four patients with type 1 and 2 diabetes between 29 and 78 years old (median of 60 years). Most patients were women 40/ $54(74.1 \%)$, with a median of 61 years. Male participants were $14 / 54(25.9 \%)$, with a median of 60 years (Table 1 ).

Table 1 - Minimal values, first quartile (Q1), median, third quartile (3Q), maximal, mean, and standard deviation of the ages of patients seen at the Nursing Education Center for Adults and the Elderly, according to gender. Ribeirão Preto, São Paulo, 2004-2005

\begin{tabular}{lcccccccc}
\hline Gender & & \multicolumn{6}{c}{ Age } \\
& N & $\begin{array}{c}\text { Minimal } \\
\text { value }\end{array}$ & Q1 & Median & Q3 & $\begin{array}{c}\text { Maximal } \\
\text { value }\end{array}$ & Mean & $\begin{array}{c}\text { Standard } \\
\text { Deviation }\end{array}$ \\
\hline Female & 40 & 29 & 48.3 & 61 & 67.5 & 78 & 58.7 & 10.8 \\
Male & 14 & 38 & 53.5 & 60 & 69.3 & 77 & 59.6 & 10.7 \\
\hline
\end{tabular}

Regarding skin color, most patients 32/54 $(59.3 \%)$ were white. As to marital status, 37/54 $(68.5 \%)$ were married. Concerning their occupation, $23 / 54(42.6 \%)$ were retired. In terms of education, it was observed that $32 / 54$ (59.3\%) of the diabetic patients had not finished primary education. As for family income, 16/54 (29.6\%) patients with diabetes mellitus indicated that they received between one and two minimal wages.

Assessment of the diabetic patients' knowledge about the disease before and after implementing SDM

When analyzing the patients' knowledge before and after implementing the Diabetes Education Program, a knowledge increase was observed, since the number 
of correct answers for each topic containing questions about diabetes increased. Values were statistically significant for every topic $(p<0.05)$ (Table 2$)$.

Table 2 - Evolution of the knowledge on diabetes mellitus in patients seen at the Nursing Education Center for Adults and The Elderly, for each of the questions about the disease. Ribeirão Preto, São Paulo, 2004-2005

\begin{tabular}{lcccc}
\hline $\begin{array}{l}\text { Knowledge on aspects about } \\
\text { diabetes mellitus }\end{array}$ & $\begin{array}{c}\text { Before } \\
\text { No }\end{array}$ & $\begin{array}{c}\text { After } \\
\text { No }\end{array}$ & Paired t & P \\
\hline $\begin{array}{l}\text { Diabetes mellitus: concept, } \\
\text { physiopathology and treatment }\end{array}$ & 368 & 665 & 11.8 & $\mathrm{p}<0.05$ \\
Physical activity & 196 & 288 & 7.7 & $\mathrm{p}<0.05$ \\
Eating & 253 & 360 & 6.7 & $\mathrm{p}<0.05$ \\
Foot care and examination & 171 & 244 & 5.3 & $\mathrm{p}<0.05$ \\
Self-monitoring & 81 & 147 & 8.3 & $\mathrm{p}<0.05$ \\
Hypoglycemia & 265 & 376 & 6.6 & $\mathrm{p}<0.05$ \\
Chronic complications & 164 & 210 & 3.5 & $\mathrm{p}<0.001$ \\
Special situations & 180 & 250 & 5 & $\mathrm{p}<0.05$ \\
Family support & 41 & 53 & 3.5 & $\mathrm{p}<0.001$ \\
\hline
\end{tabular}

\section{DISCUSSION}

Characterization of the study population according to sociodemographic variables

The median age of the 54 patients with type 1 and 2 diabetes was 60 years. Hence, the study population consisted of adult and elderly patients (Table 1 ).

In Brazil, a multi-center study about the prevalence of diabetes mellitus found that the frequency gradually increases after the age of 50 . This same study emphasized the importance of diabetes as a health problem associated with the progressive tendency of population aging that has been confirmed in Brazil(11).

In terms of gender, in this study, most participants were women (Table 1 ). National and regional studies have reported that there is no significant difference regarding the prevalence of diabetes mellitus in terms of gender in Brazil ${ }^{(11-12)}$. The fact that women were the majority in the CEEAI may be associated to the fact that it is easier for women to attend health institutions and that their work hours are more flexible.

In terms of marital status and occupation, it was observed that $37 / 54(68.5 \%)$ and $23 / 54(42.8 \%)$ were married and retired, respectively ${ }^{(13)}$.

As for education, 32/54 (59.3\%) patients had not finished the primary level, which is in agreement with the study on the prevalence in Brazil and Ribeirão Preto - SP(11-12).
Assessment of diabetic patients' knowledge about the disease before and after the implementation of SDM

In order to implement the Diabetes Education Program, at the beginning of the study, the researchers assessed the patients' knowledge about the disease in terms of its physiopathological and nutritional aspects, its treatments, as well as physical activity, foot care, self-monitoring, hypoglycemia, chronic complications, special situations and family support. This evaluation had two main goals. The first was to diagnose the patients' knowledge needs regarding their disease, with a view to planning the Diabetes Education Program. The second concerned the assessment of the knowledge these patients acquired after implementing the program. This procedure is in agreement with another study, in which the authors report that an effective evaluation of the results of a diabetes education program requires data collection in both the pre-intervention and post-intervention stages ${ }^{(14)}$.

The evaluation of the Diabetes Education Program was carried out by comparing the knowledge the patients obtained about their disease before and after the educational program implemented at the CEEAI.

When analyzing the patients' knowledge, before and after implementing the Diabetes Education Program, a knowledge increase was observed, since patients gave more correct answers for each topic regarding diabetes, with statistically significant values in all topics $(p<0.05)$.

Regarding the general aspects of diabetes concept, physiopathology and treatment - there was a larger increase in the knowledge, which is in agreement with other studies ${ }^{(7-10)}$.

In the present study, it is observed that there was an increase in the diabetic patients' knowledge about the disease. However, it cannot be stated that the knowledge the patients acquired actually had an effect on changing their lifestyles; that is, it cannot be affirmed that their behaviors changed. Furthermore, in the present study, the increase in knowledge regarding physical activity and eating was statistically significant.

The results show that the diabetes education strategies, in general, had effects on the patients' knowledge, including behavior skills. However, the results regarding the knowledge acquired about the diet were smaller than more general knowledge about diabetes, which is in agreement with other studies ${ }^{(7-10)}$. 
There is a lack of studies about diabetes education interventions performed by nurses and nutritionists. This is relevant as these health professionals play a role of great responsibility in educating diabetic patients toward self-management.

Some authors have also reported a significant difference in all measures used to assess the patients' knowledge about aspects related to diabetes and nutrition $^{(7-8)}$

A systematic review of controlled and randomized studies about type- 2 diabetes patients' ability to self-manage their disease revealed that, in approximately six months, the patients' knowledge about eating habits improved. On the other hand, the results from the intervention regarding physical activity vary considerably ${ }^{(10)}$.

The change in the diabetic patients' behavior in terms of their lifestyle is affected by the knowledge they have about their disease, as well as other factors like the meaning of the disease, risks and control methods.

One study assessed the effectiveness of group education and found that it was effective in increasing the knowledge about self-monitoring capillary glucose, compared before and after implementing the educational program ${ }^{(13)}$.

Blood glucose self-monitoring helps to achieve glucose control, contributes to recognize hyper and hypoglycemia, as well as to reduce episodes of acute complications. Thus, it helps to avoid the onset of chronic complications or, at least, reduces their incidence ${ }^{(1)}$. In agreement with this study, the introduction of glucose self-monitoring at home was one of the activities proposed in the educational program. This activity aimed to improve glucose control and significantly contributed to adjust the prescribed therapy, providing an important tool to help diabetic patients make decisions when facing hyper or hypoglycemia episodes.

Considering capillary glucose control as an important part of the diabetic patient treatment, since it offers knowledge of their day-to-day glucose fluctuations, the authors proposed to teach patients to self-monitor their capillary glucose, using the glucose monitor. The patients checked their capillary glucose at the CEEAI every Tuesday, and at home whenever they were asked to.

A significant increase in the patients' knowledge about foot care was observed in this study. It is worth emphasizing that the topics developed were based on the patient' needs identified in the beginning of the study. The interventions performed were: lectures, foot examinations and a workshop to teach foot care. These procedures are in agreement with another study and the Brazilian Diabetes Society guidelines $^{(15-16)}$.

The study also showed a significant increase in the knowledge about how to detect the signs and symptoms of hypoglycemia. The researcher reinforced this topic since it has been proven that patients in intensive treatment with insulin present an increase in hypoglycemia episodes ${ }^{(1)}$, which was also confirmed during the implementation of the SDM.

Regarding the special situations, the interventions were performed during the parties and celebrations programmed at the Center, like Christmas, Easter, June Festival and birthdays. During these moments, the behaviors associated with social events were reinforced, as well as attitudes toward the food plan.

It has been reported that family support is a fundamental aspect for diabetic patients to achieve self-management of the disease ${ }^{(7)}$. In this study, it was observed that, in the beginning, 41/54 (75.9\%) patients had family support, which increased to 53/ $54(98.1 \%)$ at the end of the study. This shows that the families were integrated into the diabetes education group at the Center. One activity that deserves special attention is the families' involvement during the nutritionist's instructions about the food plan.

It is important to understand that the diabetic patient's knowledge about the disease is the basis to achieve diabetes self-management, but knowledge acquisition does not necessarily mean a change in behavior $^{(7,10)}$.

In this sense, it is the responsibility of the multi-professional team to, in addition to provide patients with all necessary information about their disease, to follow them for some time, visiting them at home and helping them make decisions on the numerous situations imposed by the disease.

Nurses play an important role in the multiprofessional team. Their role as caregivers is observed in nursing consultations and group activities. These activities allow for learning about the patients' real needs for coping with the disease. Furthermore, it helps them to become co-participants in their care. The patients' effective participation in these activities should motivate them to make changes in their lifestyle 
with a view to increasing their self-esteem, their will to learn, to manage diabetes, and to improve their acceptance of the disease in their family and social context.

Nursing care delivery to diabetic patients comprises a group of health instructions, aiming to develop their awareness and encourage changes in their behavior concerning their problem. The main purpose is to help them act to prevention and reduce the harms caused by the natural course of the disease. By investing in the development of the patients' ability and skills to manage the disease, the nurse would offer a significant contribution to patients' capacity to lead a more independent life.

On the other hand, it is believed that the vectors affiliation, belonging, communication, learning, cooperation, pertinence, and tele between the multi-professional team and the patient were the key to the results obtained in this study.

\section{CONCLUSIONS}

The characterization of the study population is one of the key elements in group studies, due to the need to know the sociodemographic and clinical features in order to implement education program, as well as to interpret the obtained results. Hence, it was found that the population in this study was composed by adult and elderly individuals, between 29 and 78 years old, mostly women, white, married, retired, without finishing primary education, and with an income between one and two minimum wages. Patients had type 2 diabetes and the time of diagnosis ranged between one and ten years. As to the patients' knowledge about the disease, there was a significant increase $(p<0.05)$, with emphasis on the topics regarding diabetes mellitus: concept, physiopathology and treatment; physical activity and eating.

Implementing the Diabetes Education Program is a great challenge for the multi-professional health team, both in terms of the ability in diabetes education and the understanding that knowledge acquisition does not necessarily mean a change in behavior. In this sense, it becomes evident that, in addition to providing patients with the necessary information about diabetes management, they should be followed for a certain period so as to collaborate with their decision making in terms of the many situations imposed by the disease.

\section{REFERENCES}

1. Diabetes Control and Complication Trial Research group DCCT. The effect of intensive treatment of diabetes on the development and progression of long-term complications in insulin-dependent diabetes mellitus. N Engl J Med 1993; 329:977-86.

2. United Kingdom Prospective Diabetes Study Group (UKPDS Group). Intensive blood glucose control with sulphonylureas or insulin compared with conventional treatment and risk of complications in patients with type 2 diabetes (UKPDS 33). Lancet 1998; 352: 837-53.

3. Plano Nacional de Prevenção e Controle do Diabetes Mellitus. Arq Bras Endocrinol Metab 1986; 30(1):24-30.

4. Grupo de Estudio de la Diabetes en Atención Primaria (GEDAPS) de la Sociedad Catalana de Medicina Familiar y Comunitaria. Diabetes mellitus tipo 2: protocolo de actuación. FMC 2000; 7 (Supl 6):1-54

5. Mazze R, Weaver T, Upham P, Simonson G, Bradley R, Sundem $S$, Kiefver R, Gordon T. Staged Diabetes Management - Decision Support (SDM-ds): an internet-based system for clinical decision making. Diabetes Res Clin Practice 2000; 50(Supl): 196 .

6. Organização Pan-Americana da Saúde. Atlas de Educación en Diabetes en América Latina y el Caribe: Inventario de Programas para personas con diabetes tipo 2. División de Prevención y Control de Enfermedades. Brasilia (DF): Programa de Enfermedades no Transmisibles; 2002.
7. Santos ECB, Zanetti ML, Otero LM, Santos MA. Os cuidados sob a ótica do paciente diabético e de seu principal cuidador. Rev Latino-am Enfermagem 2005 maio-junho; 13(3):397-406. 8. Rickheim P, Weaver T, Flader J, Kendall D. Assessment of Group Versus Individual Education: A Randomized study. Diabetes Care 2002; 25:269-74.

9. Clement S. Diabetes self-management education. Diabetes Care 1995; 18:1204-14.

10. Norris SL, Engelgau MM, Narayan KMV. Effectiveness of self-management training in type 2 diabetes: a systematic review of randomized controlled trials (Review). Diabetes Care $2001 ; 24: 561-87$.

11. Malerbi DA Estudo da prevalência do diabetes mellitus no Brasil. [tese]. São Paulo (SP): Faculdade de Medicina/ USP; 1991.

12. Torquato MTCG, Montenegro RM, Viana LAL, Souza RAHG, Lanna JCB, Durin CB, Foss MC. Prevalência do diabetes mellitus, diminuição da tolerância à glicose e fatores de risco cardiovascular em uma população urbana adulta de Ribeirão Preto Diabetes Clín 2001 maio-junho; 5(3):183.

13. Leite SAO, Bracaraense Costa P, Guse C, Dorociaki JG, Teodorovicz R, Martinatto JS, Silveira MC, Niclewicz EA. Assessment of the impact of Staged Diabetes Management in a private health system in Curitiba, Brazil. Diabetes Res Clin Practice 2000; 50(Suppl 1):54.

14. Tomky DM, Weaver TW, Mulcahy K, Peeples MM. Diabetes education outcomes: what educators are doing. Diabetes Educ $2000 ; 26: 951-54$ 
15. Barth R, Campbell LV, Allen S, Jupp JJ, Chisholm DJ. Intensive education improves knowledge, compliance and foot problems in type 2 diabetes. Diabet Med 1991; 8:111-7.

16. Sociedade Brasileira de Diabetes. Tratamento e acompanhamento do diabetes mellitus: diretrizes da Sociedade Brasileira de Diabetes. Rio de Janeiro: Diagraphic; 2006 